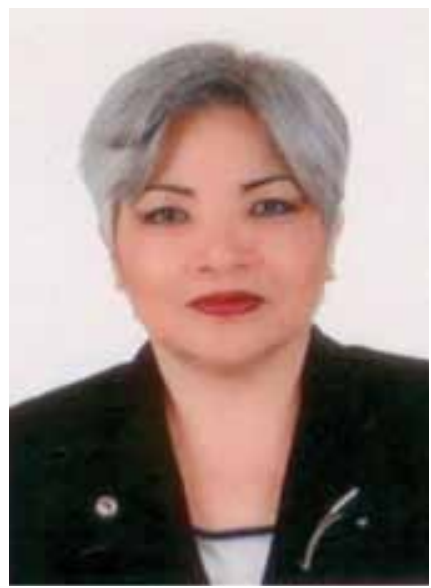

PASOS Y HUELLAS

\title{
Un hombre esencialmente bueno: In Memoriam de Francisco Polanco
}

\section{Mu-Kien Adriana Sang *}

Tú y yo lo sabemos y lo adivina el tiempo roto en el vacío de cada reloj que fue marcando los instantes de tus momentos más amados. En ese día que dejaste pérdidas entre nosotros tu sonrisa y esa mirada alegre de niño ilusionado, el fruto generoso de tu siembra en vida y tanto amor a lo largo acumulado queda, en el corazón de los hombres buenos, ese lugar que tú siempre has transitado...

Carlos Gracia Escarp,

Elegía a un hombre bueno, 2010

Hace algunos años, después de haber enterrado a mi padre, decidí abrazarme a la filosofía taoísta. Era mi mecanismo personal de mantenerlo vivo en mi corazón. Leyendo a Lin Yutang, un gran filósofo del siglo XX y también su escritor favorito, aprendí a ver la vida de manera distinta. Aprendí a valorar al ser humano y a la vida en su justa dimensión, porque, como decía Yutang: "En esta vida hay lágrimas y lo que importa, después de todo, es ante todo lo que lloramos". Partiendo de estas lecturas maravillosas, creo que no hay mejor definición para Polanco (como le llamábamos siempre) que la de un hombre esencialmente bueno.

Conocí a Francisco Polanco hace más de 30 años, cuando ambos prestábamos servicios a otras instituciones de Educación Superior. Mi hermana mayor laboraba bajo su dependencia en la Universidad Nacional Pedro Henríquez Ureña y siempre me mencionaba a su jefe, "el Sr. Polanco".

Francisco, en ese entonces, decidió alzar el vuelo hacia nuevas playas, por lo que el destino nos unió a ambos, casi en la misma época, en la Pontificia Uni- versidad Católica Madre y Maestra, institución que lo acogió con los brazos abiertos. Traía una estela de realizaciones y fue contratado para desempeñar una función académica. La alegría de reencontrarnos fue inmediata. Al poco tiempo, fue designado para desempeñarse como miembro del Comité de Evaluación de Propuestas del Proyecto para el Apoyo a Iniciativas Democráticas (PID). Ahí nos acercamos más y fue un gran aliado en esa nueva experiencia. En el año 2002, cuando el PID llegaba a su fin, Francisco fue designado como Vicerrector Académico, mientras que yo estaba a cargo del nuevo Departamento de Educación. Cuando fui llamada a sucederlo en el puesto, en el 2006, nos reunimos y me dio valiosos consejos y me entregó los asuntos pendientes. Él quedó al frente del Ciclo Básico hasta su fallecimiento. Así, pues, fuimos primero compañeros de labores y después vivimos, con mutuo aprecio, los cambios en las posiciones jerárquicas de la Institución. iCuántas vueltas da la vida!

Todavía me sorprende su humildad. Francisco, maestro a toda prueba, educador convencido de que la educación era la única salida que tiene el país, ocupó a lo largo de su vida diversas posiciones: maestro de primaria, maestro de los maestros, funcionario privado de alta y mediana responsabilidad. Todas y cada una de esas posiciones las desempeñó con gran empeño y tesón, mucha dignidad y, sobre todo, sin estridencias. Las posiciones, los ascensos o descensos que implicaba ocupar cada nueva posición, significaban siempre un nuevo reto. Su sencillez dignificaba las nuevas tareas y, lo más importante, lo convertían en un ser cada vez más grande y más humano. ("El hombre superior ama su alma, el hombre inferior ama su propiedad", decía Lin Yutang.)

\footnotetext{
'Doctora en Historia por la Escuela de Altos Estudios de Ciencias Sociales de París. Reconocida autora de libros y artículos sobre Historia Dominicana. Vicerrectora Académica de la Pontificia Universidad Católica Madre y Maestra, Recinto Santo Tomás de Aquino, para el período 2006-2010. Actual Vicerrectora de Postgrado de esta misma universidad en el Campus de Santiago y en el Recinto Santo Tomás de Aquino. Para contactar a la autora: mu-kiensang@pucmm.edu.do
} 
He comentado siempre que la dignidad, la humildad y la bondad eran los signos característicos de Francisco Polanco. Así vivió y así murió. Cuando oí de sus labios que había sido diagnosticado con una enfermedad terminal, me derrumbé. Me pregunté incesantemente, ¿por qué la vida impone tan duras pruebas?, ¿por qué a él, si todavía tenía mucho que darle a la educación? Intenté consolarlo, como pude. Decidí acompañarlo durante largos y tortuosos días de dolor físico. (El hombre solo está en el camino a la grandeza cuando es lo suficientemente sincero consigo mismo como para reconocer su pequeñez, decía también Ling Yutang)

Francisco pronto tendrá un año que partió al infinito. Imagino que está sentado al lado de Dios, en quien confiaba y a quien amaba profunda y plenamente. Todavía me parece

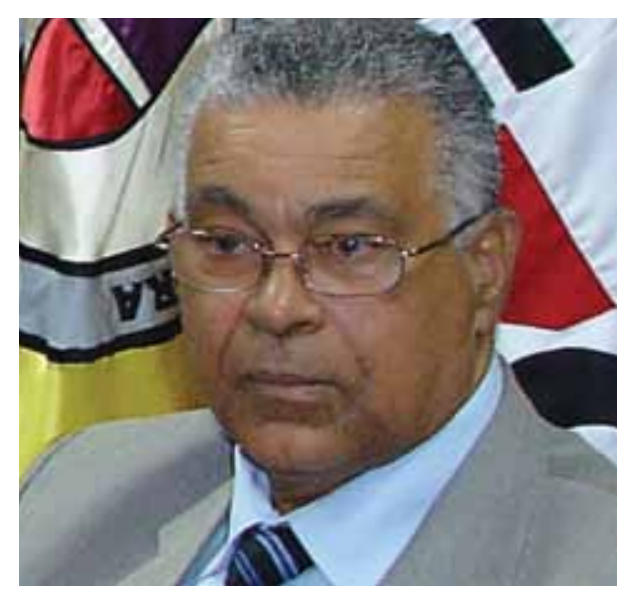

Hoy nos acompaña su recuerdo. Nadie olvidará su caminar lento por los pasillos del Edificio A, ni su risa tímida a veces y estruendosa otras tantas, como tampoco sus enseñanzas y sus análisis sobre la educación. Todos los que lo conocimos y compartimos con él lo recordamos y lo recordaremos siempre como un gran maestro, como un gran hombre, bueno y humilde.

Igual que llora la vida este adiós tuyo sienten tu pérdida pastores y rebaños, de luto el aroma a romero y a tomillo. Tristes resuenan campanas y campos, cómo nos cubre de pena tu ausencia, vacías se ven las calles sin tu presencia, callado el pueblo en su doloroso llano. Revivirán en el horizonte tu risa y tu llanto y los días respetarán sin falta tu memoria verlo por los pasillos de esta Universidad con su paso lento, desgarbado y vistiendo sus pantalones anchos y largos para su tamaño. En varias oportunidades coincidimos como jurado de los premios del Ministerio de Educación. Él era jurado de Didáctica y yo de Historia. En una oportunidad aumentaron la dotación que nos daban. Quería comprarse un sillón reclinable. Me contó que utilizaría el dinero para complacer ese deseo. Tiempo después le pregunté si lo había hecho. Me respondió que había comprado uno sencillo, porque aunque el dinero le alcanzaba "iEse sillón era demasiado para mí! iMe daría vergüenza tenerlo en mi casa!"

Al enfermar supo llevar su condición con la dignidad que lo caracterizó siempre. Sin quejas, sin protestas de ningún tipo y sin lamentarse, buscó la manera de no ser un fardo pesado para nadie.

A veces, siento que está todavía con nosotros, porque escucho su voz y su tono cuidadoso en las tantas reuniones similares a las que habíamos participamos juntos. Sonrío aún cuando siento que alguien repite el final de las frases, porque me recuerda a Polanco, quien repetía las dos últimas sílabas de las oraciones, era un eco constante en los diálogos con él. Era su forma de concentrarse. Así descubrí que cuando no lo hacía en mis reuniones periódicas con él, era porque estaba distraído. como permanece la cruz herida en el calvario,

como quema y hiela el viento...

Cómo nos duele ahora tu lugar en el camposanto.

Lo sabes bien, le iremos dando largas al olvido,

con nosotros vas para siempre...

Rey del ritmo de tic-tac que diste cuerda a todas las horas,

lentas las manecillas se arrastran, ahora que nos has dejado.

Carlos Gracia Escarp, Elegía a un hombre bueno, 2010

\section{Referencias consultadas}

Gracia Escarp, C. (2010). Elegía a un hombre bueno. Extraído el 18 de diciembre de 2010, de http://desdebarcelona.lacoctelera.net/ post/2010/07/19/elegia-un-hombre-bueno

Lin Yutang, extraído el 18 de diciembre de 2010, de http://es.wikipedia. org/wiki/Lin_Yutang 